\title{
sciendo
}

DOI 10.2478/sbe-2019-0008

SBE no. 14(1) 2019

\section{DECLINE IN STATE CHARTERED BANKS: CAUSES, CONCERNS, AND CONCLUSIONS ${ }^{1}$}

\author{
JAMES Hannah \\ School of Business, University of Central Arkansas, USA \\ CASEY Michael \\ School of Business, University of Central Arkansas, USA \\ MITCHELL David \\ School of Business, University of Central Arkansas, USA
}

\begin{abstract}
:
This paper investigates the decline of state chartered banks in the rural states Alabama, Arkansas, Nebraska, Oklahoma, and Tennessee. We use bank capital as the dependent variable for the mixed model regression analysis. We analyze both state and bank specific variables to determine which factors have more influence on bank equity capital. The findings indicate that as bank equity capital increases, the number of state chartered banks decreases. We also find that small agriculture business loans increase as equity capital increases, showing that in our sample of rural states agriculture is significant in providing a capital buffer for state chartered banks. However, we find that loans secured by farmland do not statistically influence bank equity capital.
\end{abstract}

Key words: banking, financial institutions, equity capital, bank charter

\section{Introduction}

The number of banks in the United States has been on the decline since the 1980s. In 1980 there were 19,069 commercial banks. By the end of 2017 that number had fallen to 4,888 (Federal Reserve Bank of St. Louis, 2018), which represents a decline of $73 \%$. The number of bank closings, consolidations, and mergers reducing the number of

\footnotetext{
${ }^{1}$ We thank the participants at the ACRE paper workshop and Society of Business Industry and Economics conference for their helpful comments. We also thank the Arkansas Center for Research in Economics (ACRE) for funding this project.
} 
banks concerns borrowers and policymakers alike. As the number of banks decrease, the largest banking institutions have grown their share of the market. The 10 largest banking institutions held $13.5 \%$ of total assets in 1980. By 2000, they held $36 \%$ (DeYoung, Evanoff, and Molyneux, 2009). This concentration continued to increase to $50 \%$ in 2010 and to above $60 \%$ in 2015 .

Community banks provide an important role in the United States economy. Small banks typically focus on relationship banking, meaning that they have a history with and knowledge of a client that goes beyond quantitative information. The Office of the Comptroller of Currency (OCC), the Federal Deposit Insurance Corporation (FDIC), and the Federal Reserve Board all have different definitions for what constitutes a community bank. The FDIC's definition takes into account total loans-to-assets, uses geographic reach as a proxy for a bank's engagement in proxy lending, excludes specialty lenders, and includes other non-asset based criteria as well (Federal Deposit Insurance Corporation (FDIC), FDIC Community Banking Study, December 2012).

The OCC and the Federal Reserve define community banks simply by asset size: $\$ 1$ billion for the OCC and $\$ 10$ billion for the Federal Reserve. This paper will use the OCC's definition of a community bank and our primary focus is on community bank decline beginning after the credit crisis of 2007.

Before the credit crisis, community banks were recognized as strong lenders for small businesses, providing over $70 \%$ of small business loans (Emmons, Gilbert, and Yeager 2004). However, community banks have been experiencing a consistent decline in small business loans since the 1990s (Jagtiani and Lemieux 2016). The credit crisis of 2007 accelerated this trend. In 2010, the Dodd-Frank Wall Street Reform and Protection Act became law. This Act completely overhauled the financial regulatory system. In an attempt to prevent another market failure like the 2007 credit crisis, regulatory expectations for banks were substantially increased. The new regulations led to a major increase in compliance costs. Small banks did not have the economies of scale in lending so the costs were spread over lower loan volume resulting in a faster decline of small banks (Pierce, Robinson, and Stratmann, 2015).

There are many different factors that appear to influence numerical bank decline. For example, small banks with assets less than 10 billion dollars are decreasing faster than larger banks with assets of at least 10 billion dollars. Location also appears to be a factor. Some states experience precipitous declines while others observe much slower declines. The data show that banks in rural states tend to have a slower rate of decline than other states.

The decreasing number of small banks is a concern for many reasons, such as the potential loss of accessibility to certain types of loans. For example, community banks offer about $77 \%$ of agricultural loans in the United States (Greene, Lux 2015). Because of the importance of agriculture, and by extension farmland, we analyze the differences across five rural states; Arkansas, Alabama, Nebraska, Tennessee, and Oklahoma. We selected these states because they are considered by the U.S. Census to be similar in rural composition.

The Census categorizes urbanized Areas (UAs) as areas with 50,000 or more people; Urban Clusters (UCs) of at least 2,500 and less than 50,000 people. "Rural" 
encompasses all population, housing, and territory not included within an urban area. (Census.gov). There are 15 states that the census considers to be more than $50 \%$ rural. There are 19 states than are more rural than the US average of $28.8 \%$ of the population.

For this study, we focus on state chartered banks. For the five selected states, almost all of the state chartered banks are classified as community banks (Afdahl et al. 2015). While there is little literature about whether bank charter is significant in bank decline, there is literature supporting important differences between state and national charters. Agarwal, Lucca, Seru, and Trebbi (2012) examine banks that are regulated jointly by both federal and state regulators. They find that state regulators are more lenient than the OCC, which regulates nationally chartered banks. Whalen $(2010,2012)$ examines new banks and determines that they are more likely to choose a state charter because maintaining a national charter entails higher explicit supervisory costs. The small size of most state chartered banks leads them to choose state regulators over federal regulators in order to observe lower regulatory expenses. This regulatory difference would suggest that state chartered banks should be less likely to decline because they are more leniently regulated; however, that is not typically the case. Using a mixed model, we attempt to determine whether state-specific or bank-specific aspects are more influential in the decline of state chartered banks. In short we attempt to determine some of factors influencing small bank decline.

\section{Literature Review}

The question of why community banks have been declining has been a heavily researched topic. The means of decline come from failure, consolidation, and mergers and acquisitions (M\&A). Emmons et al. (2004) determines how community banks struggle with diversifying credit risk. Small banks are unable to exhaust portfolio diversification benefits and are often being geographically concentrated. Geographic concentration causes banks to be more impacted by changes in the local economy. Aubuchon and Wheelock (2010) conclude that many of the bank failures that occurred between 2007 and 2009 were the result of the local economic conditions.

DeYoung et al (2009) did a comprehensive study of M\&A of over 150 cases and concluded the primary causation of consolidation stemmed from innovation in financial and technical fields that created new optimal functions of operations. Lu and Whidbee (2013) show that banks that are more financially fragile are more likely to fail, as well as de novo banks. Since the 2007 financial crisis, many different factors have been deemed significant in influencing bank failures such as brokered deposits (Rossi 2010), real-estate loans (Cole and White 2011), and audit quality (Jin, Kanagaretnam, and Lobo 2011).

Mergers also contribute to numerical bank decline. Marsh and Norman (2013) find that there have been 6.5 mergers for every 1 bank failure since 1990 . There is general consensus about the driving factors regarding consolidation and M\&A for financial institutions. Berger (1999), Amel, Barnes, Panetta, and Salleo (2004), and Dymski (1999) have all analyzed the forces driving consolidation. They determine that as the industry developed, deregulation was important for financial institutions to take advantage of the 
new opportunities. This deregulation led to the ability of banks to merge with and acquire other banks in order to expand quickly enough to maximize benefits of the new developments.

The Dodd-Frank Act of 2010 brought a new perspective for the decline of community banks which revolved around regulatory burdens. Marsh and Norman (2013) predicted that the Act would have costly impacts on community banks. Feldman, Schmidt, and Heinecke (2013) did a study attempting to quantify these costs for banks with less than $\$ 1$ billion in assets. They determine that the smaller the community bank, the more its profitability levels were negatively affected by the additional compliance costs. In addition, Mason (2016) finds a decline in certain types of lending by community banks due to a limited secondary market or fear of litigation. The tight grasp on community banks has decreased their avenues for doing business, making success more difficult.

An important aspect in a bank's ability to keep its doors open is the level of equity capital it is able to maintain. Gambacorta (2004) shows the importance that a bank's capital has on its lending behavior. Bank equity capital essentially acts a buffer for shocks or unexpected losses. However, maintaining a large buffer can cause problems for small banks. Because capital is being held in reserve, investment opportunities are lost, which can lead to lower average returns (Sageworks 2015).

There has been surprisingly few studies addressing the impacts of national versus state charter on small bank decline. Banks can choose between being nationally chartered or state chartered. Under a national charter, a bank is regulated by the OCC and under a state charter a bank is regulated by their State Regulator and either the FDIC or the Federal Reserve. The consensus in the literature is that state chartered banks have more lenient regulations than nationally chartered banks. Rezende (2011) finds that joint, or concurrent bank inspections, increase with size, so smaller state chartered banks are less likely to be checked by the OCC.

Rauch (2010) finds that after the 2007 credit crisis, the OCC responded more rapidly and efficiently than the FDIC. National banks were more efficient at reducing liquidity creation and lending to reduce balance sheet fragility than state banks. These results were robust and highly significant. Whalen $(2010,2012)$ suggests that national regulation has higher explicit costs for supervision, which lead many new banks to begin with a state charter. Beginning in 2003, new banks shifted from seeking national charters to seeking state charters. Now around $85 \%$ of new banks seek state charters. While many of the differences between charter types have disappeared over the years, there are still some major ones remaining. One example is a fee that the OCC revised in 2002 regarding minimum base amount, which had a negative effect on smaller banks.

Agarwal et al (2012) finds that the same rules can be implemented in a completely different manner depending on who is implementing them. This inconsistency is due to institutional design differences and varying incentive plans. When a bank selects a state charter, it tends to pick the more lenient regulator. They also find that some aspects of a bank are significantly more likely to be downgraded by federal regulators than by state regulators. These areas make up the CAMELS rating: capital adequacy, quality of assets, quality of management, earnings, liquidity, and sensitivity to market risks. 


\section{Data}

For this study we gather data from a multiple sources. In an attempt to view the decline of state chartered banks from two angles, we collected both state-specific data as well as bank-specific data. To study bank equity, we formulated a hierarchical statistical model representing variation within banks over time, and variation between states over time. The following model is estimated:

BankEquity $_{i j t}=\alpha_{0}+\beta X_{i t}+u_{i t}+\theta Z_{i j t}+e_{i j t}$

We combine the "micro" and "macro" parts of the model where Bankequity $y_{i j t}$ is the dependent variable. The intercept term is $\boldsymbol{\alpha}_{\boldsymbol{0}}, \boldsymbol{B} \boldsymbol{X}_{i t}$ is a matrix of banks and coefficients over time, and $\boldsymbol{\theta} \mathbf{Z}_{i j t}$ is a matrix of states and coefficients over time. We assume that $\mathrm{u}_{\mathrm{jt}}$ and $\mathrm{e}_{\mathrm{ijt}}$ are normally distributed.

Because of the importance of agriculture to small banks as well as to rural states, we selected five states with similar rural area from which to collect data: Alabama, Arkansas, Nebraska, Oklahoma, and Tennessee. We selected 25 banks from each state and collected annual data from years 2005 through 2010. Table 1 contains some descriptive information of this sample.

\section{Table 1 Descriptive Statistics Equity Capital}

\begin{tabular}{|l|l|l|l|l|l|}
\hline State & N & Mean & Min & max \\
\hline AL & 275 & $1.92 \mathrm{e}+07$ & $1.58 \mathrm{e}+07$ & 1150000 & $8.55 \mathrm{e}+07$ \\
\hline $\mathrm{AR}$ & 275 & $2.91 \mathrm{e}+07$ & $2.56 \mathrm{e}+07$ & 4216000 & $1.44 \mathrm{e}+08$ \\
\hline OK & 352 & 9920578 & $1.30 \mathrm{e}+07$ & 200500 & $1.04 \mathrm{e}+08$ \\
\hline NE & 297 & $1.33 \mathrm{e}+07$ & $1.50 \mathrm{e}+07$ & 1666000 & $1.02 \mathrm{e}+08$ \\
\hline TN & 275 & $2.28 \mathrm{e}+07$ & $1.91 \mathrm{e}+07$ & 3579000 & $1.45 \mathrm{e}+08$ \\
\hline Total & 1474 & $1.83 \mathrm{e}+07$ & $1.92 \mathrm{e}+07$ & 200500 & $1.45 \mathrm{e}+08$ \\
\hline
\end{tabular}

BankEquity represents the real dollars of equity capital held by each bank. This data was collected from the US Bank Locations website, which is a comprehensive bank directory that gathers its data from various governmental agencies. We chose BankEquity as the dependent variable because it is a crucial aspect a bank's success. Meh and Moran (2010) show how scarcity in bank capital can lead to a decrease in bank lending. We define the independent variables below.

- $\quad$ STCHAR. Number of state chartered banks (state banking department reports)

- SBLSEC. Amount of small business loans secured by nonfarm, nonresidential properties (US Bank locations) 
- $\quad$ SBLFRM. Amount of small business loans secured by farmland (US Bank Locations)

- HPI. Housing price index data (Federal Reserve Economic Data)

- GDPPC. Unadjusted GDP per capita for each state (Federal Reserve Economic Data)

- UNEM. Unemployment rate (Federal Reserve Economic Data)

- SBLCl. Amount of small business loans made up by commercial and industrial lending (US Bank Locations)

- $\quad$ SBLAG. Amount of small business loans to finance agriculture (US Bank Locations)

STCHAR represents the number of state chartered banks. This data was collected from annual reports filed by each states' bank department. SBLSEC represents small business loans that are secured by nonfarm, nonresidential properties. This data was collected from the US Bank Locations website. SBLFRM represents small business loans that are secured by farmland. This data was collected from the US Bank Locations website. We chose this variable because of the importance that small banks have in the agricultural lending sector.

HPI represents the housing price index data collected from the Federal Reserve Economic Data. Tsatsaronis and Zhu (2004) identify a strong connection between bank lending and housing prices. GDPPC represents GDP per capita collected from the Federal Reserve Economic Data. UNEM represents unemployment rate collected from Federal Reserve Economic Data. SBLCI represents commercial and industrial loans. The data for this was collected the US Bank Locations Website, as was SBLAG, which represents the amount of small business loans to finance agriculture.

For all of the small business lending variables, we divide the total amount of loans in that category per bank per year by the total amount of assets per bank per year. Before we began, we wanted to understand how bank equity capital changed from year to year. Figure 1 shows the equity capital dispersion over time. We find that the state chartered banks often did not make drastic changes to their bank equity capital before 2010. After 2010, many banks began increasing the level of equity capital held, due partly to the enactment of the Dodd-Frank Wall Street Reform and Protection Act. 


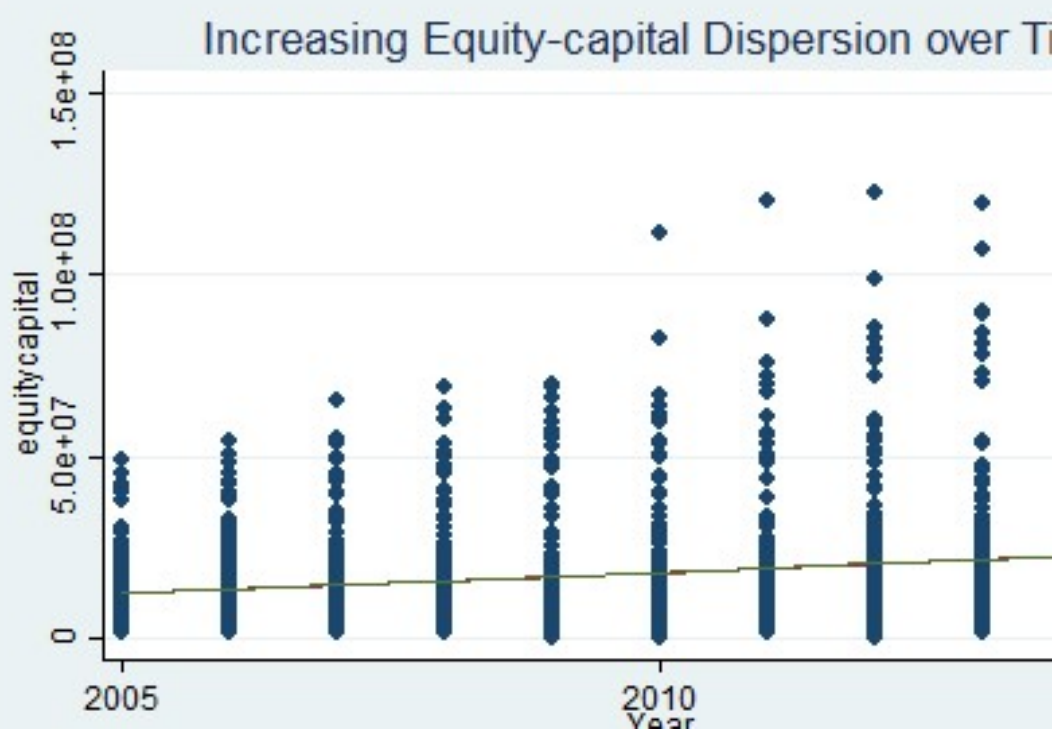

Figure 1: Equity-Capital Dispersion Over Time

We use a mixed model to take into account the fixed variables, such as the FIPS codes used to identify the states and the FDIC certificates which are used to identify specific banks. Figure 2 shows the differences across states for each bank.

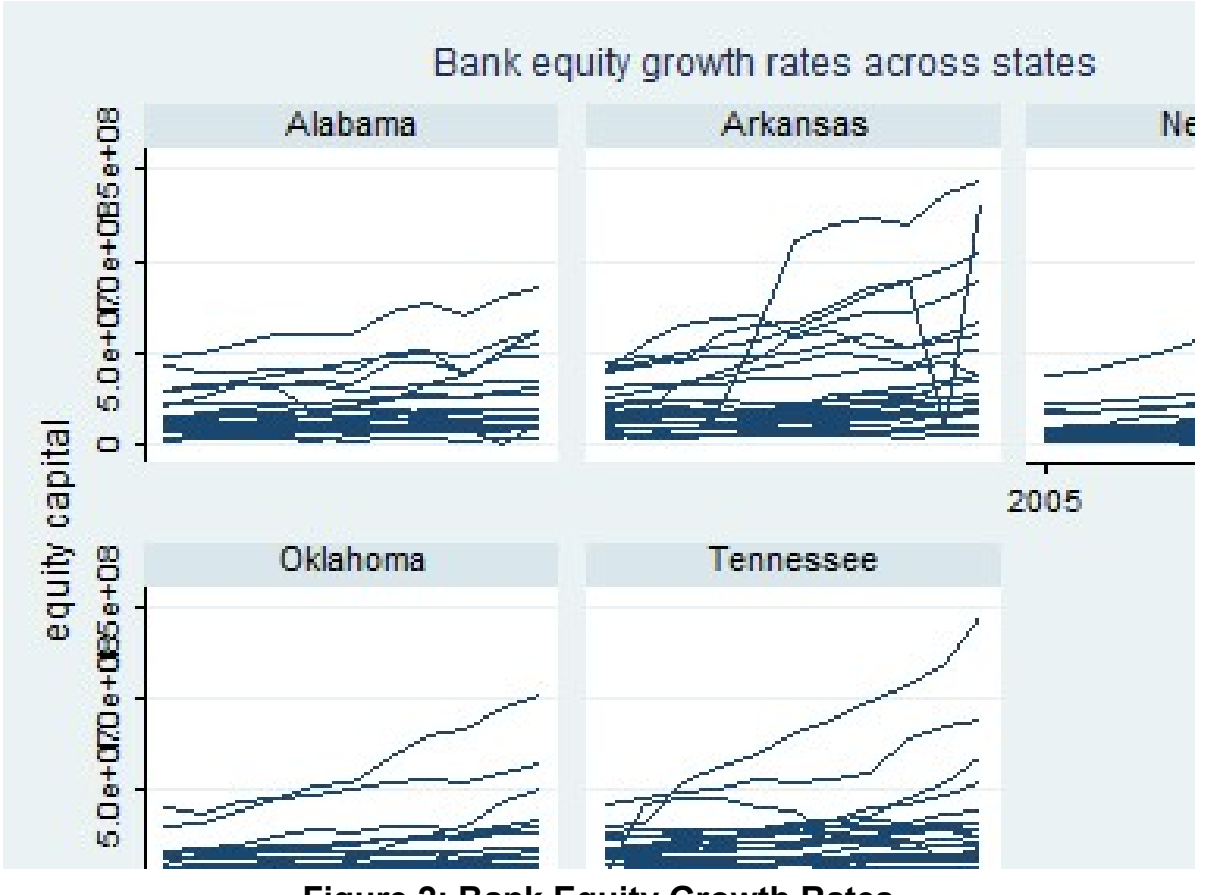

Figure 2: Bank Equity Growth Rates 
The data is not normally distributed but rather exhibits large tails as shown by figure 3 .

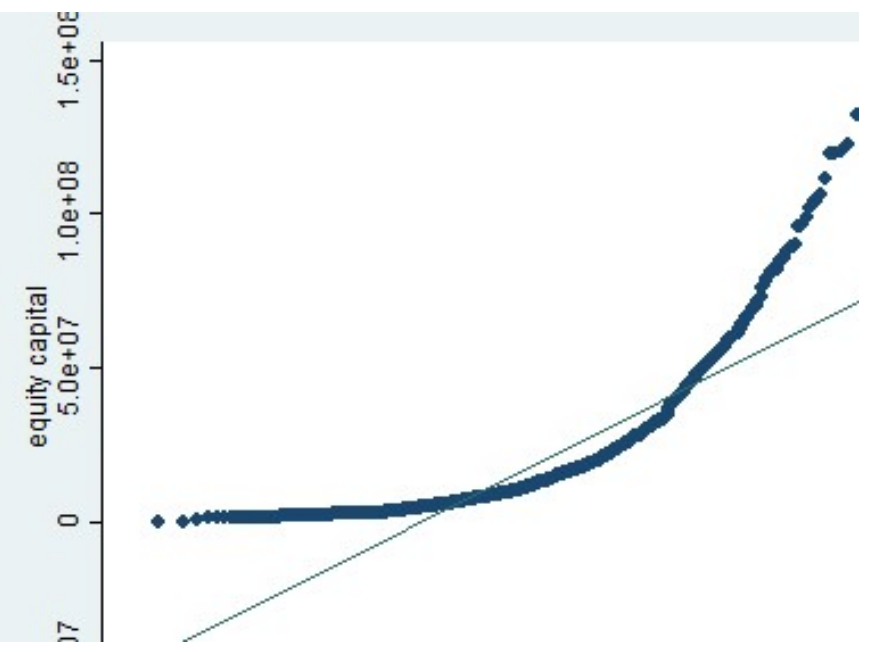

Figure 3: Quantiles of equity capital against quantiles of normal distribution

\section{Methodology}

Equity capital is hierarchically structured in banks within states over time. We use a two-level random effects model which provides random effects at both the individual bank level and the state level. We chose random effects modeling because it is more flexible than fixed effects modeling. Each bank or each state can have its own slope and yintercept whereas fixed effects modeling would force each individual (state or bank) to have the same slope as the others. Random effects models can also explain the specific differences between higher-level entities. Fixed effects estimation does, of course, provide individual y-intercepts. (Wooldridge 2010)

\section{Results}

Table 2 contains summary statistics and the results from the mixed model regression analysis. 


\section{Table 2: Model Results}

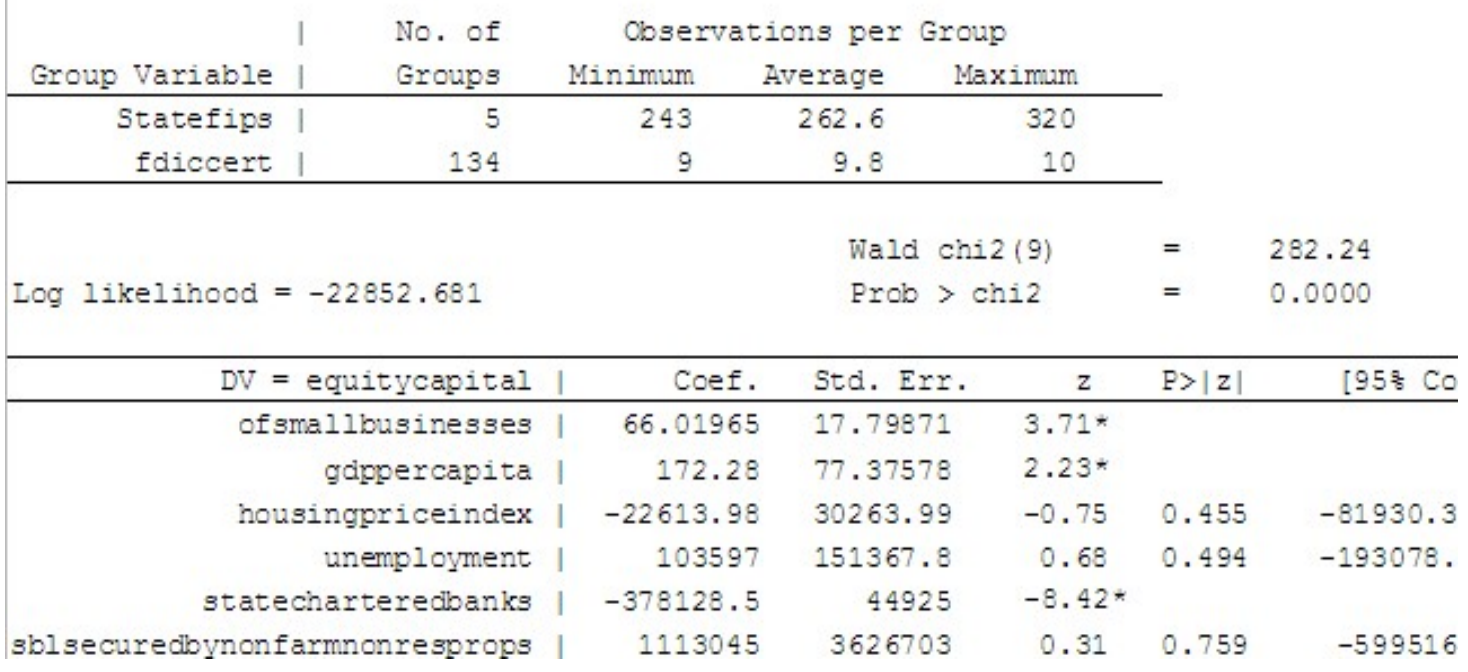

We begin our explanation with the state variables: unemployment, GDP per capita, housing price index, and the number of state chartered banks. We find the surprising result that GDP per capita was only almost significant with a large, negative coefficient. This means that as GDP per capita increases, bank equity capital tends to decrease. ${ }^{1}$ We hypothesized that as the average person in each state became wealthier, banks would have an easier time increasing their equity capital.

Both housing price index and unemployment were not statistically significant in our regression. The number of state chartered banks was highly statistically significant, which is what we expected. The surprising aspect is that this variable had a large, negative coefficient. This means that as the number of state chartered banks increases, the level of equity capital decreases. This result combined with that of the GDP per capita variable show that state chartered banks are more likely to stay in business when GDP per capita is increasing. However, this also means that state chartered banks struggle more with higher levels of equity capital.

Next our analysis reviews the bank specific variables: small business loans secured by nonfarm, nonresidential properties, small business loans secured by farmland, small business commercial and industrial loan, and small business loans to finance agriculture. Small business loans secured by nonfarm, nonresidential loans is statistically significant and largely negative, which suggests that our hypothesis that loans secured by farmland are vital for state chartered banks in our sample of southern, rural states. Small business commercial and industrial loans were not significant in our regression, further strengthening our hypothesis.

Small business loans secured by farmland is statistically significant with a very large positive coefficient, showing that as these types of loan increase, so does equity

1 As a robustness check we also ran the regression using different lags, different covariance matrix specification, and robust standard errors. These regressions are qualitatively similar in that the same variables are significant, the coefficients retain the same sign, and the coefficients are similar sizes. 
capital. The assumption that farmland is crucial to state chartered banks in rural states proves to be accurate. The fact that small business loans to finance agriculture was not even close to being statistically significant was surprising to us. However, through further investigation, that there are many different avenues to gain access to agricultural loans, such as federal lending agencies that can offer lower interest rates. We hypothesize that this added competition is making it more difficult for state chartered banks to provide competitive pricing on loans to finance agriculture.

Interestingly the intra-class correlation contained in Table 3 shows that within bank and state level correlations are almost equal.

\section{Table 3: Correlations}

\begin{tabular}{|l|l|}
\hline \multicolumn{2}{|l|}{ Intra Class Correlation } \\
\hline Across Bank & 0.7219 \\
\hline Within Bank & 0.1467 \\
\hline State Level & 0.1315 \\
\hline
\end{tabular}

\section{Concluding Remarks}

This study identifies three significant variables that influence the equity capital in state chartered banks in our sample of rural states: number of state chartered banks, small business loans secured by nonfarm, nonresidential properties, and small business loans secured by farmland. We find a couple of surprising results. 1) GDP per capita is almost statistically significant, but not quite and 2) that small business loans to finance agriculture is not statistically significant at all.

Even though GDP per capita was not significant, it was almost significant with a large coefficient. This finding implies that equity capital could have a tendency to decrease as GDP per capita increases, which provides a better chance for state chartered banks to stay open. However, the fact that these banks are more likely to be successful with lower equity capital raises additional concerns. One such concern is how they will be able to respond to economic shocks, considering that more equity capital provides a cushion for banks that helps reduce the rate of failure.

The finding that state chartered banks are more likely to stay open leads to a lower level of equity capital is concerning. Equity capital provides an important buffer for banks against unexpected shocks and losses. The inability of state chartered banks to successfully maintain higher levels of capital could lead to them being more at risk to sudden economic shocks.

\section{References}

Afdahl, B., Allred, P., Bacon, R., Cooper, C., Cotney, D., Deal, S., Fite, T., Gonzales, G., Hall, M., Kingry, L., Noring, V., Seymour, S. (2015). "The public benefit of state services regulation." Conference of State Bank Supervisors white paper. 
Agarwal, S., Lucca, R. Seru, A., and Trebbi, F. (2012), "Inconsistent Regulators: Evidence From Banking." The Quarterly Journal of Economics. Vol. 129, pp. 889-938.

Amel D, Barnes C, Panetta F, Salleo C (2004) "Consolidation and efficiency in the financial sector: a review of the international evidence." Journal of Banking \& Finance. Vol. 28, pp 2493-2519.

Aubuchon, C.P. and Wheelock, D.C. (2010), "The geographic distribution and characteristics of US bank failures, 2007-2010: do bank failures still reflect local economic conditions?", Federal Reserve Bank of St Louis Review, Vol. 92 No. 5, pp. 395-415.

Berger AN (2003) "The economic effects of technological progress: evidence from the banking industry." Journal of Money, Credit \& Banking Vol. 35, pp. 141-176.

Cole, R.A. and White, L.J. (2011), "Déjà Vu all over again: the causes of US commercial bank failures this time around", Journal of Financial Services Research. Vol. 42 No. 1, pp. 5-29.

DeYoung, Robert, Douglas D. Evanoff, and Philip Molyneux (2009). "Mergers and Acquisitions of Financial Institutions: A Review of the Post-2000 Literature," Journal of Financial Services Research, vol. 36. No. 2, pp. 87-110.

Dymski G.A (1999) The bank merger wave: the economic causes and social consequences of financial consolidation. Armonk, New York. M.E. Sharpe.

Emmons, W. R., Gilbert, R. A., \& Yeager, T. J. (2004). Reducing the risk at small community banks: is it size or geographic diversification that matters? Journal of Financial Services Research, 25(2-3), 259-281.

Federal Deposit Insurance Corporation. "Statistics on Depository Institutions." https://www5.fdic.gov/sdi/main.asp?formname=compare Accessed March 20, 2017.

Federal Reserve of St. Louis. "Total Assets, All Commercial Banks." https://fred.stlouisfed.org/series/TLAACBW027SBOG. Accessed April 26, 2018

Federal Reserve of St. Louis. "Commercial Banks in the U.S" https://fred.stlouisfed.org/series/USNUM. Accessed April 26, 2018.

Feldman, R., Schmidt, J., and Heinecke, K. (2013) "Quantifying the Costs of Additional Regulation on Community Banks." Minneapolis Federal Reserve.

Gambacorta, L. (2004). "Does bank capital affect lending behavior?" Journal of Financial Intermediation. Vol. 13, No. 4, pp. 436-457.

Greene, R., and Lux, M. (2015). "The State and Fate of Community Banking." Mossavar-Rahmani Center for Business and Government. Associate Working Paper Series No. 37.

Jagtiani, J., \& Lemieux, C. (2016). Small business lending after the financial crisis: A new competitive landscape for community banks. Economic perspectives, 3, 1-30.

Jin, Y.J., Kanagaretnam, K. and Lobo, G.J. (2011), "Ability of accounting and audit quality variables to predict bank failure during the financial crisis", Journal of Banking \& Finance, Vol. 35 No. 11, pp. 2811-2819

Lu, W., Whidbee, D. (2013). "Bank structure and failure during the financial crisis." Journal of Financial Economic Policy. Vol. 5, No. 3, pp. 281-299.

Marsh, T., and Norman, JW (2013). "The Impact of Dodd-Frank on Community Banks." Wake Forest Univ. Legal Studies Paper No. 2302392.

Mason, B. (2016). "The Federal Government Assesses Dodd-Frank's Impact on Financial Institutions." RMA Journal. Vol 98, pp. 58-61.

Meh, C., and Moran, k. (2010). "The role of bank capital in the propagation of shocks." Journal of Economic Dynamics and Control. Vol. 34, No. 3, pp. 555-576.

Peirce, H., Robinson, I., and Stratmann, T. (2015). "How Are Small Banks Faring Under DoddFrank?" CATO Institute. Research Briefs in Economic Policy, no. 20.

Rauch, C. "Bank fragility and the financial crises: Evidence from the U.S. dual banking system." International Finance Review. Vol. 11. pp. 33-86. 
Rezende, M. (2011), "How do joint supervisors examine financial institutions? The case of state banks", Finance and Economics Discussion Series No. 43, Federal Reserve Board, Washington, DC.

Rossi, C.V. (2010), "Decomposing the impact of brokered deposits on bank failure: theory and practice", working paper, Robert H. Smith School of Business, University of Maryland, College Park.

Sageworks Bank Information (2015). "Bank Equity Capital."

Tsatsaronis, K., and Zhu, H. (2004). "What drives housing price dynamics? Cross-country evidence." BIS Quarterly Review. March. Pp 65-78.

U.S. Census. "2010 Urban and Rural Classification" https://www.census.gov/geo/reference/ua/urbanrural-2010.html Accessed April 26, 2018.

Whalen, G.W. (2010), "Why do de novo banks choose a national charter?" OCC Economic Working Paper No. 2010-2012, Office of the Comptroller of the Currency, Washington, DC.

Whalen, G.W. (2012), "Recent de novo bank failures: how important is supervisor choice?" OCC Economic Working Paper No. 2012-1, Office of the Comptroller of the Currency, Washington.

Wooldridge, J. M. (2010). Econometric analysis of cross section and panel data. MIT press. 